\title{
IMPACT OF COVID-19 IN BANGLADESH STOCK MARKET
}

\author{
Sunjida Haque \\ Business Graduate \\ Dhaka, Bangladesh \\ E-mail: haquesunjida@gmail.com \\ Dr. Tanbir Ahmed Chowdhury \\ Professor \\ Department of Business Administration \\ East West University, Bangladesh \\ E-mail: tanbir@ewubd.edu
}

\begin{abstract}
The world's big economies are roiled and going under a devastating threat amid the impact of the COVID-19 pandemic. No country will be safe as this virus will eventually outbreak everywhere, regardless of how countries prepare to avoid it. The economic ramification as well as the stock market crisis will be uncertain due to the extended suspension of economic activities in almost every country. No wonder, the clattered stock markets of Bangladesh which have already got the adjective of "the worst stock market in the world" because of inefficient and irrational fluctuations in previous years will experience a colossal crisis due to the pandemic. The article provides an investigation on comparable analysis of the impact on stock markets of Bangladesh, Dhaka stock exchange, and Chittagong stock exchange, before and after the pandemic situation with current market data. We also examine the potential consequence of policy interventions to the market and the investors during a pandemic.
\end{abstract}

Keywords: COVID-19, Bangladesh Stock Market, Market Operators, Pandemic.

\section{INTRODUCTION}

At this moment in time, the coronavirus Covid-19 epidemic is the prescribed global threat to mankind and the significant difficulty we have faced since World War II (Coronavirus Disease COVID-19 Pandemic | UNDP in Bangladesh, 2020). As of writing this on $9^{\text {th }}$ August, Covid-19 has affected 188 countries across the world, with about 20 million confirmed cases and more than 700000 people lost their lives ("Covid-19 Pandemic," 2020). Therefore, this breakout is considered as a Public Health Emergency of international concern and officially proclaimed as a global pandemic by the World Health Organization on March 11, 2020(Statement on the Second Meeting of the International Health Regulations (2005) Emergency Committee Regarding the Outbreak of Novel Coronavirus (2019-NCoV), 2020). This pandemic was first confirmed in Bangladesh by The Institute of Epidemiology, Disease Control and Research (IEDCR) on 8 March 2020 and its first death on March 18, 2020(Express, 2020).It is reflected from figure 1 
that as of July 30, 2020, the death rate approximately 154\% higher than March 31, 2020, despite a nation-wide lockdown imposed by the government. The total number of confirmed cases around the country is growing at breakneck speed and has reached more than 2 hundred 25 thousand as of August 11, 2020 (Bangladesh Coronavirus, 2020). According to statistics, amongst the most ill-protected countries to be affected by the rapidly expanding virus, Bangladesh has been pinpointed as one of the $25^{\text {th }}$ (COVID19 | Water Aid Bangladesh, 2020). The severity onslaught of Covid-19 seriously dented the country's economy which was already in a depressing state with major indicators such as negative export-import growth, significant revenue drop, shrinking private sector investment, rising non-performing loans documented in 2019 (Mohiuddin, 2020).

Because of market analysts, the capital markets of Bangladesh passed a hazardous time over the last 12 months for instance, the Dhaka Stock Exchange (DSE) nosedived to a new 41 month low in December 2019 (Hamim, 2020). The unprecedented impact on the stock market, suspension of all kinds of trading, settlement, and official activities triggered by Covid-19 produce possibly persistent national economic disruption.

The Dhaka Stock Exchange was established as East Pakistan Stock Exchange Association Ltd on April 28, 1954. Formal trading of the bourse began in 1956. The service on the stock exchange continued uninterrupted until 1971. The trading was suspended during the liberation war in 1971. Trading on DSE resumed in 1976 with a change in the economic policy of the then government. Since then the stock exchange has continued its journey and development activities. On August 10, 1998, automated on-line screen-based trading system began.

The Dhaka Stock Exchange is registered as a public limited company. It is a Selfregulatory organization and its activities are regulated by Articles of Association, Own Rules, Regulations and Bye-laws, Companies Act-1994, Securities and Exchange Ordinance 1969, and Securities and Exchange Rules 1987. After the successful operation of DSE, the Chittagong stock exchange (CSE) was established in 1995 which also helps to meet the increased demand of the capital market. Automated trading systems have been introduced in both DSE and CSE. In the history of Bangladesh, there were two market crashes, viz; in 1996, it was a speculative bubble and in 2011, the market was overvalued.

The Chittagong Stock Exchange (CSE) began its journey on 10th October of 1995 from Chittagong City through the cry-out trading system with the promise to create a state-of-the-art bourse in the country. Founder members of the proposed Chittagong Stock Exchange approached the Bangladesh Government in January 1995 and obtained the permission of the Securities and Exchange Commission (SEC) on February 12, 1995, for establishing the country's second stock exchange. The Exchange was comprised of twelve Board members and run by an independent secretariat from the very first day of its inception. CSE was formally opened by the then Honorable Prime Minister of Bangladesh on 4th November 1995.

This paper aims at focusing on the pre-2020 situation of the stock market, of both DSE and CSE, and how it is reacting presently to the Covid-19 pandemic using the following variables: share price index, circuit breaker, interruption of trading hours, etc. Furthermore, the paper points out some key attempts taken by the government to alleviate the pandemic's economic threat. Finally, this paper analyzes the impacts of those measures during this pandemic situation. 


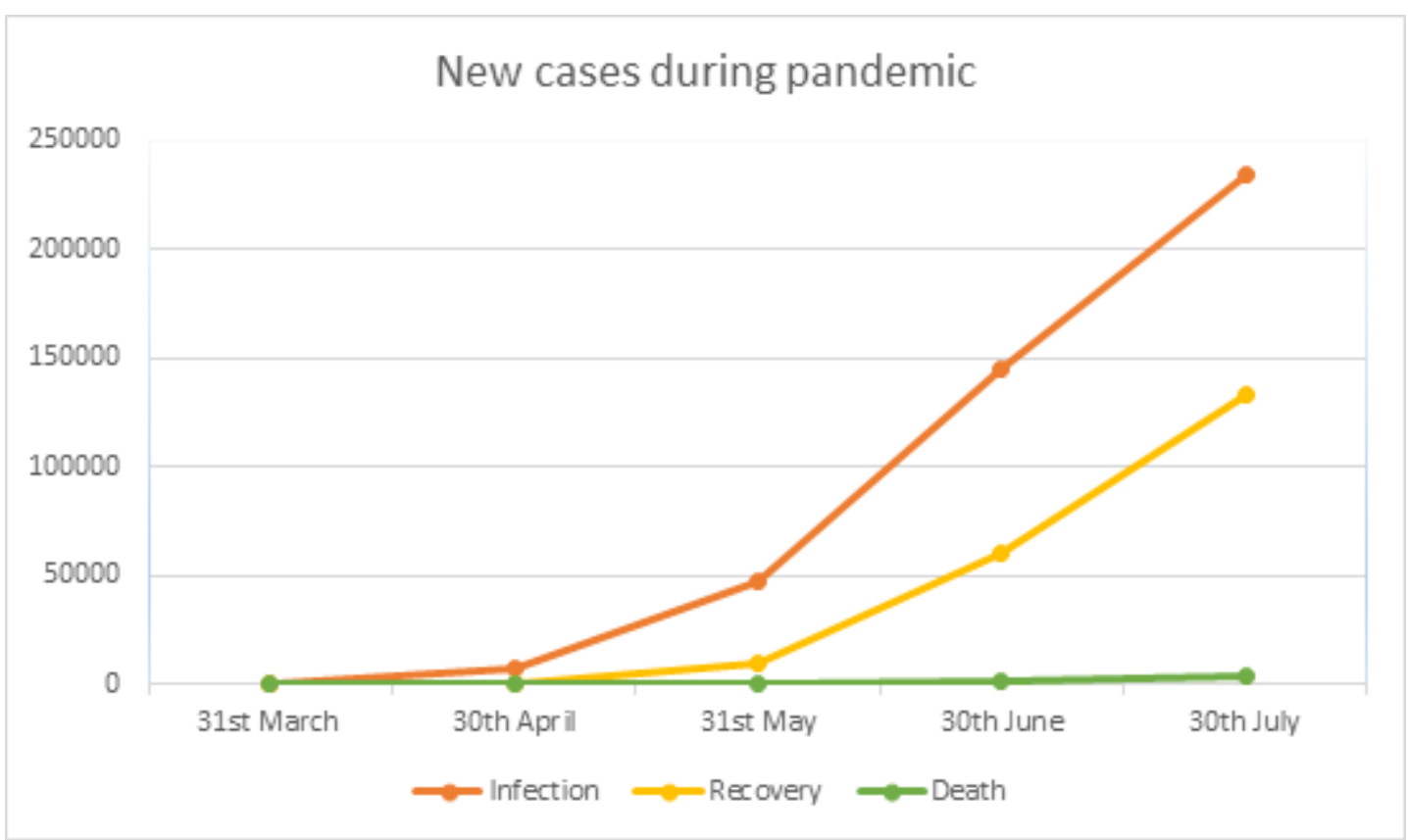

Figure 1. Illustration of the total number of infection, recovery, and death rates increases from March 2020 to July 2020.

Source: Online briefing of IEDCR. Data collected from31st March to $30^{\text {th }}$ July.

\section{LITERATURE SURVEY OF RECENT PANDEMIC}

By late December of 2019, the Chinese government informed WHO about various cases of pneumonia with unknown etiology. The Hunan seafood market in Wuhan city which is an emerging business hub of China is where this wide-spreading virus primarily originated and within the first fifty days, killed over and above eighteen hundred and infected over seventy thousand people (Shereen et al., 2020). Therefore, bats could be the possible primary reservoir as it has close genetic similarity to bat coronaviruses, and also this contagious virus is a pathogenic viral infection caused by severe acute respiratory syndrome coronavirus 2 (SARS-COV-2).

South Korea was the second country to experience a major outbreak of Covid-19. As of writing this, the US tops the list of affected countries with nearly 5 million cases and more than one hundred sixty-seven thousand deaths, closely followed by Brazil, India, and Mexico(New Cases of COVID-19 In World Countries, 2020). In South Asia, India's caseload rises to the World's third-largest after the government lifted its lockdown after two months of restrictions, followed by Pakistan. In Bangladesh, the daily infection has been recorded 24.14 percent while the fatality rate has been 1.30 percent on the $21^{\text {st }}$ week of infection (Developer), n.d.). The daily testing rate remained below 100 per day till March 25, however as a spike has been seen in the number of corona-virus cases the testing booths, as well as the testing rate, has increased significantly to 87 and 1227988 respectively. Nationwide Restriction were imposed to curb the virus imposed on March 26, 2020 weeks after the country's first Covid-19 cases were confirmed have been gradually eased from May $31^{\text {st }}$ even though the country logged a soaring number of infections and deaths.

The on-going corona-virus pandemic has had a large scale and serious implications upon financial markets which lead to major economic turmoil around the world. In the last week of February 2020 the world saw all major stock markets around the glove crash, leaving the investors traumatized. During this period, the CSI 300 index in China decreased by 12.1 percent 
of its value, whereas the FTSE MIB index in Italy declined by 27.3 percent of its value(COVID19, 2020). One of the most widely followed stock indices in the United States, the S\&P 500 tumbled by 11.5 percent and on 24th February, a 3.4 percent reduction results in the biggest oneday sell-off for two years. Since the financial crisis in 2008, this was the worst week for stock markets around the world(Choking Global Stock Markets, 2020). Economists stressed that the global economy will contract $4.9 \%$ in 2020 which is worse than its previous forecast of a $3 \%$ contraction(Otani, 2020). However, stock markets worldwide nearly healed back to the previous shape from late March as soon as multiple packages have been announced to revive their pandemic hit economies by almost all the countries. Consequently, the S\&P 500 index regained 37 percent to 3066, the Euro Stoxx 50 recovered 35 percent to 3229 and the Sensex also rebounded 29 percent to 33605 by $18^{\text {th }}$ Junefrom late March(Why Is Bangladesh's Stock Market Bearish When Global Stocks Are on Bull Run?, 2020).

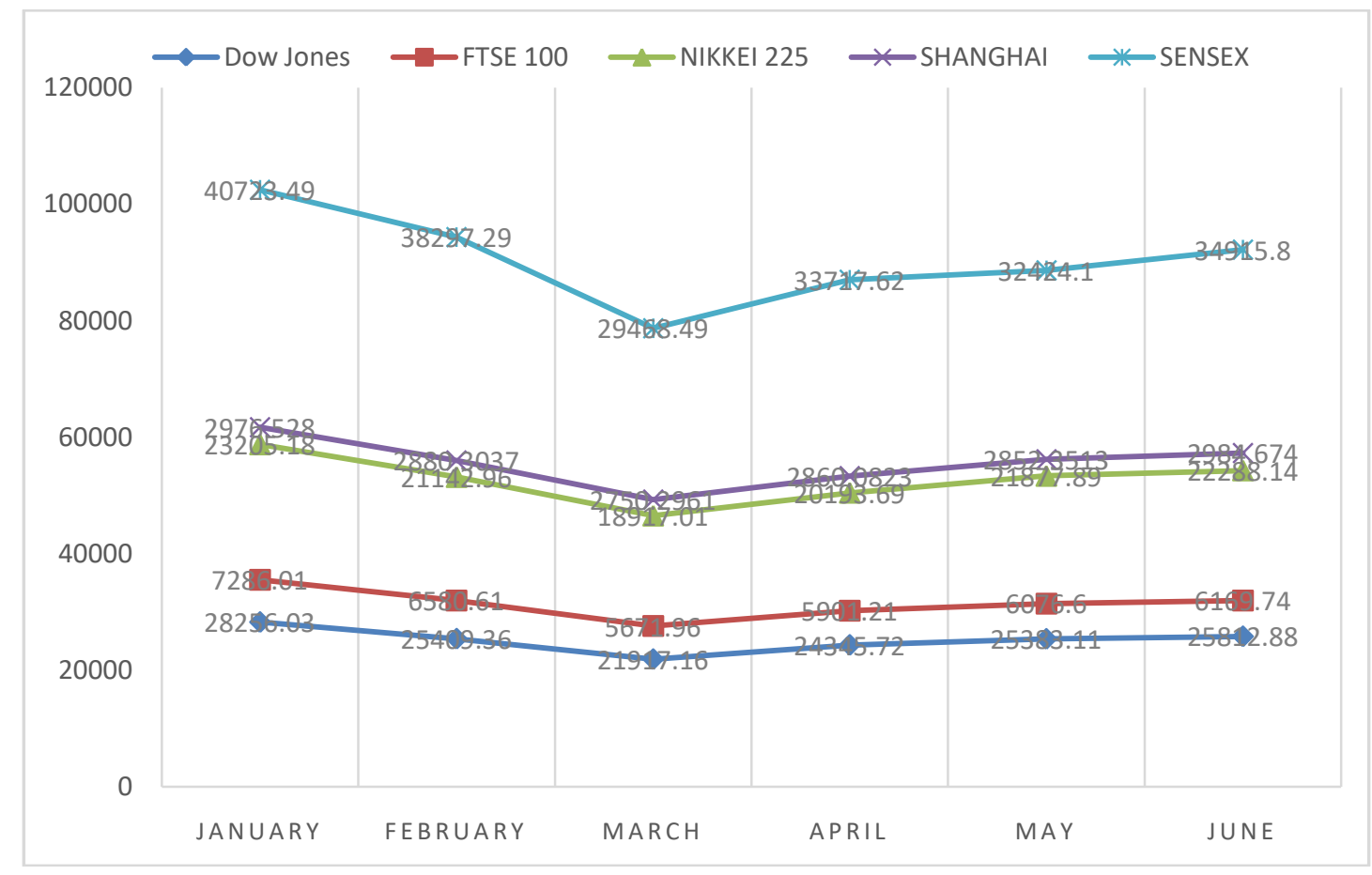

Figure 2. This figure plots the reaction of stock markets of five renowned stock exchanges, Dow Jones, FTSE100, NIKKEI 225, SHANGHAI, and SENSEX during the pandemic. The data were collected based on the average month-end index of each month from January 2020 to July 2020. Source: tradingeconomics.com.

The already rattled stock market in Bangladesh has begun to reflect the adverse impacts of the coronavirus pandemic since February 2020. The Dhaka and Chittagong stock exchanges had to stay shut from March 26, 2020, to May 31, 2020 to contain the contagion, however, thereafter a sharp decline in trading activities was observed owing to economic and financial uncertainty. On June 5, 2020, the trading value of DSE was at TK 430 million which was 13 years low due to the threat of the novel coronavirus. Along with daily market volatility of 2.20 percent the market value of equities tumbled by 11.50 percent From February 27, 2020, to June 10, 2020. Although the government publicized an enormous stimulus package amounting to TK 
103,117 crore in addition to other aid packages, DSEX dropped about 1 percent to 3960 in June. 8.2 percent GDP growth has been forecasted for the next fiscal year by the government despite the bad shape of the economy (Tk 568,000 Crore Budget Unveiled; 8.2pc GDP Growth Target Set, 2020).

\section{OBJECTIVES OF THE STUDY}

This study followed the inductive approach to understand the effect of Covid-19 on the stock markets in Bangladesh. The specific objectives of the study are as follows:

- To appraise the situation of Bangladesh stock Market during the pandemic.

- To examine the role of regulatory authority for the development of the Bangladesh stock market

\section{SCOPE AND METHODOLOGY OF THE STUDY}

The present study has been carried out to evaluate the performance of the Bangladesh stock Market during the pandemic. The analysis has been conducted mainly on data from secondary sources.

To examine and evaluate the predominating impact on Bangladesh stock markets, we have analyzed quantitative and qualitative data. The relevant data and information were collected from Dhaka Stock Exchanges, Chittagong Stock Exchange, Stock Markets Reports, and Bangladesh Securities and Exchange Commission, different websites and published materials etc. In this article, we analyzed data from December 2019 to July 2020 of Bangladesh stock markets.

We have tried to assess the performance of the stock market through the measurements of variables such Trading days and hours, Number of security listing, All price share indices Total trade-in Value \& Volume, Market Capitalization, Price Earnings Ratio, Issues Traded, and Monthly Turnover, Circuit Breakers, etc.

The present paper is organized in the following manner. Section one gives an introduction to the study. Section two presents the literature survey of the recent pandemic, section three details the objectives, scope \& methodology of the study. Section four gives an overview of the Bangladesh stock market during the pandemic, section five details the Policy measures and their implication on the stock market; finally, six provides the conclusion and findings of the study.

\section{APPRAISAL OF BANGLADESH STOCK MARKET DURING COVID-19}

\section{Trading days and hours}

The Dhaka Stock Exchange (DSE) and Chittagong Stock Exchange have been closed since March 26 aligned with the government's general holiday aimed at stopping the widening coronavirus pandemic. Bangladesh is the only country in the world where stock trading has remained closed for more than 3 months and resumed its operations from May 31, 2020. The total trading days in FY 2019-20 is 210 days seeing that the market remained closed for 66 days due to the pandemic. The regular trading hour for the capital market is from 10:30am to 2:30 pm, a four-hour trading session. By the terrible pandemic news across the globe, from March 19, 2020, the trading time had been reduced by 1 hour, starting at 10:30am and continuing until 1:30 p.m. On March 19' 2020, Bangladesh Securities and Exchange Commission (BSEC) set an emergency circuit break on all listed stocks caused a three hours delay as trading started at 
2:00pm until $2.30 \mathrm{pm}$. As the frightening situation is spreading with the significant number of deaths and infections amid pandemic, bourses amended the trading hours from 10:00am to $1: 00 \mathrm{pm}$, rather than $10: 30 \mathrm{am}$ to $1: 30 \mathrm{pm}$ on June 18 to incorporate with the banking transaction hours. Later on 8th July, after almost four months of interruption, both the stock exchanges reverted to the original full hours of the trading session starting from 10:30 am to 2:30 pm.

\section{Number of security listing}

Apart from all the bad news, the number of listings of securities has an upward trend. The number of listed securities data of Dhaka Stock Exchange and Chittagong Stock Exchange was reported at 590 units and 331 units accordingly in June 2020. These records are an increase from the previous year of 587 units and 323 units for DSE and CSE respectively.

\section{All price share indices}

In the pre-pandemic period, December 2019, DSE broad index (DSEX) went down by 1012.32 points from January 1st2019 and which is the lowest in 42 months since June 2016 and later settled at 4452.90. Since the market crash in 2010-2011, 2019 was a complete nightmare for the stock market as the blue-chip index DS30 hit almost a 7 year low in the last month of this year. The port city's bourse, Chittagong Stock Exchange also saw a sharp fall with CASPI plunging 2854 points to finish the year at 13505. In the pandemic period, On March 9, just a day after Bangladesh confirmed 3 cases of Covid-19, DSEX, the benchmark index, shed 279 points, registering the biggest single-day fall since its inception in 2013. Despite the investment made by banks in the stock market, the positive momentum failed to sustain as jittery investors dumped their shares. After setting the circuit breaker, DSEX settled at 4008 points on March 25 by losing 10 percent over the past three months. Meanwhile, The Chittagong Stock Exchange also ended lower, with CASPI settling 2177 points lower from December 2019 at 11328 . After resuming the bourses, stocks had some downward trend but posted a modest gain in the last week of FY 201920 and closed at 3989.09 points. The Chittagong Stock Exchange also ended marginally higher with CASPI soaring 59 points to settle at 11321 .

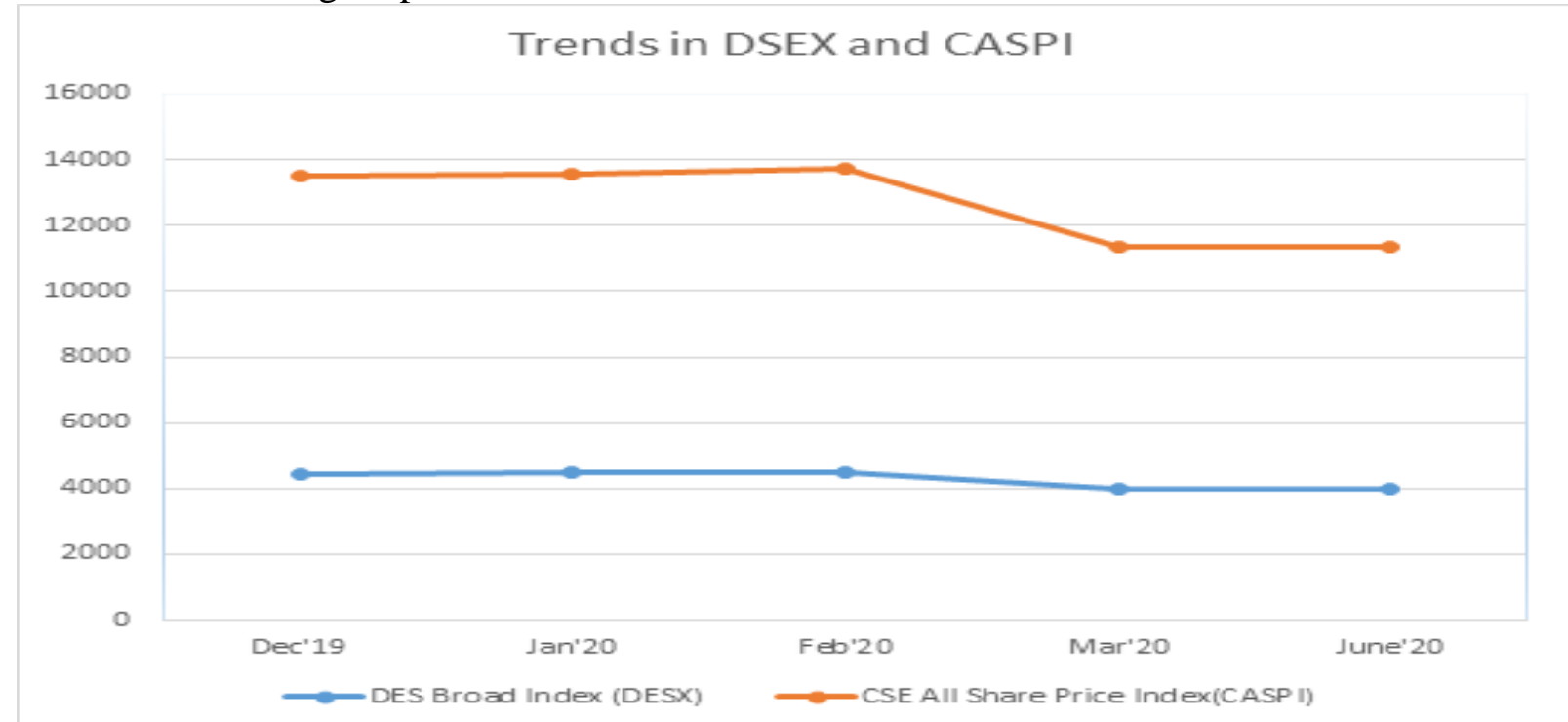

Figure 3. Dhaka Stock Exchange Broad index and Chittagong Stock Exchange all share price index from December 2019 to June 2020.

Source: DSE and CSE websites. 


\section{Total trade-in Value \& Volume}

The already deteriorating Dhaka stock market's month-end total trade was 144316 in December 2019 which declined by $81.3 \%$ due to concerns brought on by the corona-virus pandemic in March 2020 and again fell by $10 \%$ in June's last day trading session. The total value of trading is higher in June than in March and December but the total volume is sinking after December.

Chittagong Stock Exchange also faced a similar market reaction as total trade was decreased by $77.6 \%$ in March than December whereas in June it has increased to 24223. The total value and total volume also rose in June after a panicky month of March.

Table 1. Total trade, value, and volume of Dhaka Stock Exchange and Chittagong Stock Exchange during December 2019 and March and June 2020.

\begin{tabular}{|c|c|c|c|c|c|c|}
\hline \multirow{2}{*}{$\begin{array}{l}\text { Month-end } \\
\text { Data }\end{array}$} & \multicolumn{3}{|l|}{ DSE } & \multicolumn{3}{|l|}{ CSE } \\
\hline & Dec'19 & Mar'20 & Jun'20 & Dec'19 & Mar'20 & Jun'20 \\
\hline Total Trade & 144316 & 26949 & 24223 & 10300 & 2301 & 1648 \\
\hline $\begin{array}{ll}\text { Total } & \text { Value } \\
(\mathrm{MN}) & \\
\end{array}$ & 5216.489 & 3481.387 & 5557.152 & 275 & $\begin{array}{l}11206449 \\
64\end{array}$ & $\begin{array}{l}22616545 \\
54\end{array}$ \\
\hline Total Volume & 242701500 & 53809765 & 53408903 & 9252000 & 3661203 & 8615602 \\
\hline
\end{tabular}

Source: DSE and CSE websites.

\section{Market Capitalization}

Market capitalization at the country's premier bourse has dropped by 8\% from December 2019 to March 2020 to TK 3122.35 billion. The market lost TK 442 billion in seven straight sessions since the confirmation of the first corona-virus case on March 8. Nevertheless, in June, the market cap slightly declined from March. The market cap of the port city bourse also ended lower in March than December but a sharp increase has been seen in June.

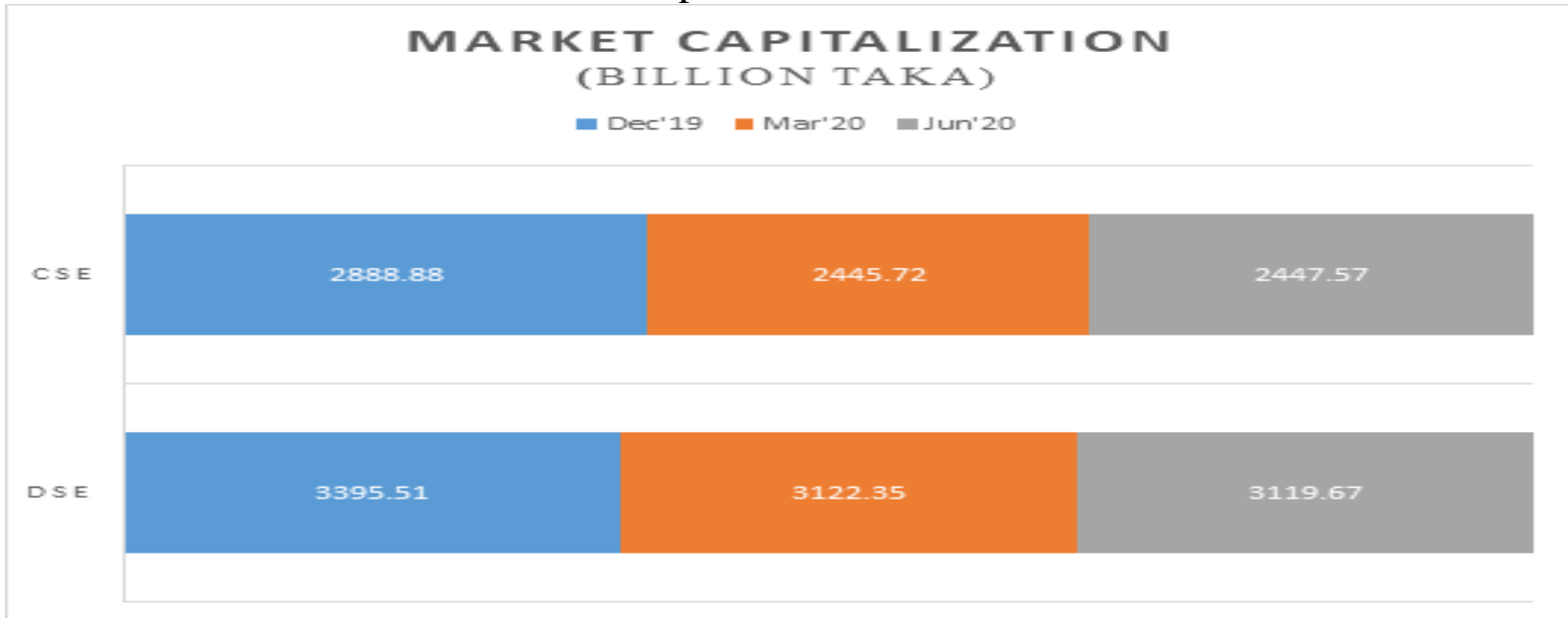

Figure 4: Market capitalizations of DSE and CSE during December 2019, March, and June 2020. Source: DSE and CSE websites.

\section{Issues Traded and Monthly Turnover}

Stocks witnessed a downward trend throughout the year 2019 where on 23rd December 299 issues were traded in DSE and CSE, 68 issues were traded. Despite the tension arising in the economic world due to the pandemic, upward trends in trading issues had noticed on the last day 
of March's trading session as 217 issues gained out of 338 in DSE and 82 issues gained out of the 157 in CSE. Both in DSE and CSE of the issues traded most of them remained unchanged on $10^{\text {th }}$ June. The highest turnover during the pre-pandemic month of December is observed which is TK 67.03 billion in DSE but in CSE, the highest turnover is TK 9.53 billion in June 2020.

Table 2. Issues traded on the bourses on December 2019, March, and June 2020.

\begin{tabular}{|l|l|l|l|l|l|l|}
\hline \multirow{2}{*}{ Trading Days } & \multicolumn{2}{l|}{ DSE } & \multicolumn{2}{l|}{ CSE } \\
\cline { 2 - 7 } & $\uparrow$ & $\downarrow$ & $\leftrightarrow$ & $\uparrow$ & $\downarrow$ & $\leftrightarrow$ \\
\hline $23^{\text {rd }}$ DEC'2019 & 121 & 95 & 83 & 36 & 20 & 12 \\
\hline $25^{\mathrm{TH}}$ MAR'20 & 217 & 74 & 47 & 82 & 47 & 28 \\
\hline $10^{\mathrm{TH}}$ JUN'20 & 25 & 16 & 238 & 18 & 11 & 63 \\
\hline
\end{tabular}

Source: The Financial Express and The Daily Star.

\section{Price Earnings Ratio (P/E ratio)}

The DSE and CSE had observed the lowest overall market price-earnings ratio as the stock market began to reflect the adverse impacts of the coronavirus pandemic. The overall market PE ratio, which is obtained by dividing the current market price by the earnings per share, came down from 11.80 (December 2019) to 10.58 in DSE and from 16.27 (December 2019) to 10.56 in CSE. Both of the bourses had registered an increase in the last month of the FY 2019-20.

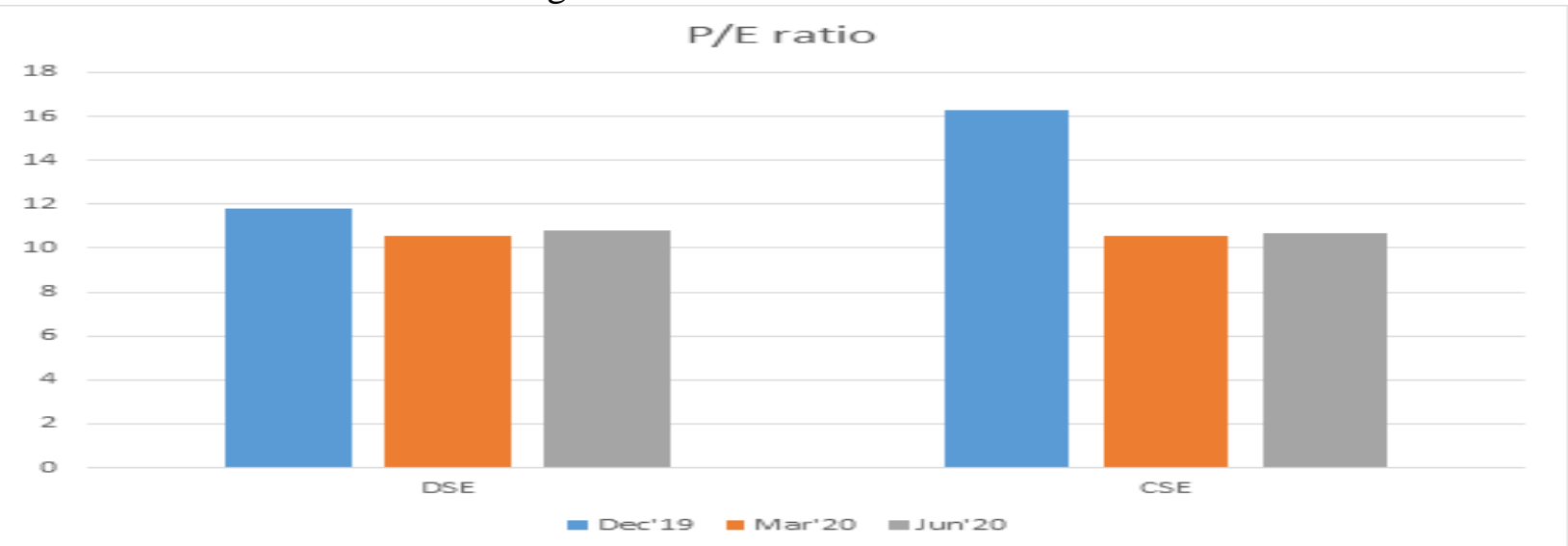

Figure 5. P/E ratio of DSE and CSE during the December 2019, March, and June 2020.

Source: Report on "Capital Market Development in Bangladesh" by Research Department of Bangladesh Bank.

\section{Circuit breaker}

The see-saw of the markets with worrying volatility urges the Government to make a move to stabilize jittery markets, as traders panic sells out of fear. Taking note of the uncontrolled market volatility amid the coronavirus fear, like many other countries, Bangladesh Securities and Exchange Commission imposed the market-wide circuit breaker and floor price for each stock on $19^{\text {th }}$ March to halt trade. Under the new emergency circuit breaker rule, all listing security's price will not go under the average closing price of five preceding days. The floor price of the day's circuit breaker will be the opening adjusted price of a stock. The higher side of the circuit 
breaker will be up to 10 percent high from the opening base price. Many countries also took such intervention to boost the ailing capital market.

Despite the new circuit breaker imposed, many investors sold out their holdings amid mounting fear over coronavirus outbreak. Later in the last week of the month, stocks rebounded strongly and yielded a positive outcome for both bourses. However, a section of market insiders demanded a withdrawal of floor prices as one of the consequences is the illiquid nature of the stock market. However, the Floor price will be lifted once the pandemic situation becomes better.

\section{POLICY MEASURES AND ITS IMPLICATION ON THE STOCK MARKET}

We will discuss the actions taken by the government and the security regulators before lockdown when the coronavirus breakthrough started, and after lockdown including budget 21 's policy to rejuvenate the stock market.

The stock market in Bangladesh was already shrinking, however, as soon as the massive panic was created by Covid-19, it is started to fall sharply albeit with the concrete effort of commercial bank investments. Thereafter, Government and stock market regulators took two steps within seven days span to stop the bleeding of this inefficient market. One of the attempts was introducing floor prices on individual scrip including block markets by the securities regulators. As soon as the regulators limit the share prices both indices have gained marginally which helped to revive the market after weeks of fall. Although junk and overvalued stocks are gained mostly as they are also included under this newly imposed circuit breaker. Junk stocks are those of the companies' stocks that have failed to provide dividends, hold annual general meetings, or have shuttered their factories.

Another big attempt was taken by the stock exchange authorities of is that keeping the stock exchanges non-operational for more than 2 months, from $26^{\text {th }}$ March to $30^{\text {th }}$ May. The reason behind this closure was to confine the deadly virus from spreading among the stock market community.

No wonder these steps were taken from the good heart of the regulators amid heightened precaution and virus fear but eventually these turn out to be bad policies for the country's economy. Many foreign as well as local investors criticized the DSE and the BSEC for the prolonged closure of trading and floor price.

Introducing the floor price generates huge confusion among the investors and professionals as this rule was quite unanticipated and unknown to them. Many investors isolated themselves from investment to understand the new rule.

One of the offset effects of the floor price regulation was the instant illiquid nature of the stock which reflects the broken stock market. Most of the stocks are stuck at the same price repeatedly and only a few stocks are traded. To illustrate, On 17 June, only 37 shares changed value out of 269 shares and daily turnover was around 60 crore per day which was 400 crore per day before the floor price was implemented.

On June $14^{\text {th }}$, due to several protests against the floor price rule, it was lifted from the block market which benefits big investors but creates dual pricing which hurts the market. As for the small investors, the previous rule will sustain which drives these companies to starve, and soon to close operations.

Stock exchanges of Bangladesh have remained closed for a significant time frame when no other stock exchanges in the world were closed for that long period. As days pass, the world came to realize that without the vaccine, this pandemic situation will not be over. So, to facilitate 
the economic movement, almost every country reopened the stock market as closing the stock market will bring more detrimental effects.

In both bourses, around 2.6 million $\mathrm{BO}$ account holders have invested their money which is immobilized because of this prolonged lockdown. Their fund should be readily available as many lost their jobs or might need for supporting themselves.

Another tragic fact is, some investors bought stocks upon taking loans which interest they will have to pay albeit stocks were not performing. Since bourses were closed, they could not sell-off their shares, besides, are compelled to pay interest which is 12-18 percent annually.

After taking over in May, the new Bangladesh Securities and Exchange Commission (BSEC) committee hold several meetings and took various initiatives along with the Ministry of Finance, Bangladesh Bank, and the NBR to bring back investors and entrepreneurs and to regain their confidence as there is no alternative to the revival of the stock market to accelerate the economy.

One of the initiatives was Bangladesh Bank announced a special package that would allow banks to form a Tk 200 crore-fund by taking financial support from the central bank for investing in the stock market.

Another point worth noting is, the stock market regulator further ordered the listed companies and their board of directors to comply with the directives regarding holding a minimum of 30 percent shares jointly by the directors, other than independent ones, within 60 working days from July 29, 2020.

These actions might bring some good vibe by rebounding the market and with more investment from foreign and local investors.

Government initiatives for the development of the stock market have appeared in the proposed budget for fiscal year (FY) 2020-21 which is welcomed by prime bourse as wellplanned and business-friendly and in favor of the general investors' expectations. To restore and to bring potency in the stock market, the government has taken six short and long-term maneuvers in the budget.

Investment of undisclosed money in the capital market by paying ten percent on such investment, subject to the lock-in period of three years. Investing undisclosed money in the stock market will be a positive scope for the investors as well as an increased flow of funds will leave a positive impact on the capital market. Furthermore, it was a demand made by many market intermediaries for a long period. However, stock market experts stressed that the provision would not bring any good to the stock market as no one would want to keep their investments under lock-in for three years as the government permitted investing in all financial schemes and instruments like cash, bank deposits, and saving certificates and there was no lock-in condition. Moreover, bank deposits and other financial instruments will be more reliable and favorable for investment than the stock market.

In the proposed budget for the financial year 2020-21, a tax incentive has been furnished to motivate the stock market and is hailed by DSE. Declaration of cash dividend instead of stock dividend has been made obligatory which is at least 50 percent of the profit of listed companies. Another policy is taken that is tax-free dividend income up to Tk. 50,000 will remain persistent in the stock market.

In the proposed budget, corporate tax has been reduced from 35 percent to 32.5 percent on non-listed companies other than banks, insurance companies, financial institutions, and mobile companies without changing the tax rate for the listed companies which essentially reduce the tax gap between listed and non-listed securities (other than financial institutions, 
telecom, and tobacco) to $7.5 \%$ instead of existing $10 \%$. The corporate tax on non-listed companies has been deducted so that these companies can get through the dire challenges faced by the country's economy due to the pandemic and also assist them in boosting the bottom-line. However, some share market participants believe that keeping the corporate tax unchanged for listed companies while reducing for non-listed companies will bring no good for the stock market. Cutting the corporate tax on the listed companies has been demanded by market operators for a long time which will minimize the tax burden, in addition, to encourage nonlisted well-performing companies to get listed in the stock market, but yet the government did the opposite which might discourage profitable businesses hold off from the capital market. . Nonetheless, the stakeholders reiterate that they will request to lower corporate tax for listed companies.

Several significant proposals requested by The Bangladesh Securities and Exchange Commission (BSEC) have gone unaddressed in this proposed budget such as reduction of capital gains tax for institutional investors and an incentive for corporations preferring bonds to bank loans.

\section{CONCLUSION}

The uncertainty of living due to the gravest threat of feared disease jeopardizing the world's overall economy as well as the global stock market.In the pandemic situation, taking on nontherapeutic precautionary means, such as, travel bans, remote working, to maintain social distancing which is quite cumbersome from the perspective of Bangladesh,has driven economic depression inescapable. Since the Corona-virus vaccine will not come any time soon, it's become a challenge for the government to maintain the health of the nation and overcome economic disparity simultaneously.

This research has intendant to explore the contrast between the before the pandemic and during pandemic's immediate effect of COVID-19 on the stock markets of Bangladesh. Also, our study attempts to reveal the efficacy of the government's initiatives and its negative aspect towards some investors. We aimed to lay out the interpretation of government responses to COVID-19 and its aftermath to the investors and the stock market itself. Though there are some arguments, the initiatives taken by the new Bangladesh Securities and Exchange Commission (BSEC) committee might upturn the bourses after a long time.

\section{REFERENCES}

Choking global stock markets: The Coronavirus effect. (2020, March 10). The Daily Star. Retrieved from https://www.thedailystar.net/coronavirus-deadly-newthreat/news/choking-global-stock-markets-the-coronavirus-effect-1878520

Coronavirus disease COVID-19 pandemic | UNDP in Bangladesh. (2020, August 9). UNDP. Retrieved from https://www.bd.undp.org/content/bangladesh/en/home/coronavirus.html

COVID19 | WaterAid Bangladesh. (2020, March 4). Retrieved from https://www.wateraid.org/bd/covid19

Covid-19 pandemic: Tracking the global coronavirus outbreak. (2020, November 20). BBC News. Retrieved from https://www.bbc.com/news/world-51235105

COVID-19: Stock market volatility 2020. (2020, February 25). Statista. Retrieved from https://www.statista.com/statistics/1105021/coronavirus-outbreak-stock-market-change/

Express, T. F. (2020, March 18). IEDCR confirms first coronavirus death in Bangladesh. The Financial 
https://www.thefinancialexpress.com.bd/public/index.php/al/iedcr-confirms-firstcoronavirus-death-in-bangladesh- 1584525528

Hamim, M. T. (2020). COVID-19 and the Capital Market Chaos (SSRN Scholarly Paper ID 3600853). Social Science Research Network. https://doi.org/10.2139/ssrn.3600853

Mohiuddin, A. K. (2020). An Extensive Review of Health and Economy of Bangladesh Amid Covid-19 Pandemic. https://doi.org/10.20944/preprints202005.0261.v1

New Cases of COVID-19 In World Countries. (2020, August 10). Johns Hopkins Coronavirus Resource Center. Retrieved from https://coronavirus.jhu.edu/data/new-cases

Otani, J. W. and A. (2020, June 24). Stocks Fall as Coronavirus Infections Surge. Wall Street Journal. Retrieved from https://www.wsj.com/articles/global-stock-markets-dow-update6-24-2020-11592989380

Shereen, M. A., Khan, S., Kazmi, A., Bashir, N., \& Siddique, R. (2020). COVID-19 infection: Origin, transmission, and characteristics of human coronaviruses. Journal of Advanced Research, 24, 91-98. https://doi.org/10.1016/j.jare.2020.03.005

Statement on the second meeting of the International Health Regulations (2005) Emergency Committee regarding the outbreak of novel coronavirus (2019-nCoV). (2020, January 30). Retrieved from https://www.who.int/news/item/30-01-2020-statement-on-thesecond-meeting-of-the-international-health-regulations-(2005)-emergency-committeeregarding-the-outbreak-of-novel-coronavirus-(2019-ncov)

Tk 568,000 crore budget unveiled; 8.2pc GDP growth target set. (2020, June 11). The Daily Star. Retrieved from https://www.thedailystar.net/tk-568000-crore-budget-2020-21unveiled-8.2pc-gdp-growth-target-set-1912729

Why is Bangladesh's stock market bearish when global stocks are on bull run? (2020, June 18). The Daily Star. Retrieved from https://www.thedailystar.net/business/news/whybangladeshs-stock-market-bearish-when-global-stocks-are-bull-run-1916441

Worldometer. (2020, August 11). Retrieved from https://www.worldometers.info/coronavirus/country/bangladesh/

\section{Copyrights}

Copyright for this article is retained by the author(s), with first publication rights granted to the journal. This is an open-access article distributed under the terms and conditions of the Creative Commons Attribution license (http://creativecommons.org/licenses/by/4.0/) 